\title{
The Institutionalization of the Presidential Secretariat in Korea, 1948-2011*
}

\author{
Yong-duck Jung, ** Yoon-ho Lee, *** and Hyun-Jong Yoo****
}

\begin{abstract}
This article analyzes the institutionalization of the presidential secretariat (PS) in Korea from 1948 to the present. The PS was poorly institutionalized from the 1940s to the 1960s, but it has rapidly expanded and differentiated since 1968. Although presidents since the democratic transition in 1987 have effectively controlled any expansion of the number of senior secretaries, the PS's total size has continued to increase, especially during the latter part of each administration. It has undergone institutional experiments responding to changing environmental challenges. The PS has become a core institution for executive and economic policy functions since 1968, at which time its expenditures began to increase steadily, enhancing its autonomy. And, socio-cultural, welfare, and education affairs have been a particular focus of institutionalization since 1987. The PS has been highly professionalized, staffed mainly with public servants and experts rather than politicians. This has caused it to be oriented toward the long term and consistency rather than the short term and flexibility.
\end{abstract}

Keywords: presidential secretariat, institutional presidency, Blue House, core executive, executive leadership, Korean government

* This research was supported by the Development Fund of Seoul National University in 2005. The original version of this article, titled "The Executive Leadership in South Korea, 1948-2010: From Charismatic to Institutional Presidency," was presented at the Working Group VII (Leadership, Governance and Public Policy) of the Annual Conference of the International Association of Schools and Institutes of Administration and the 28th International Congress of Administrative Sciences, Nusa Dua, Bali, Indonesia, July 12-17, 2010.

** Yong-duck Jung is a professor in the Graduate School of Public Administration at Seoul National University.

*** Yoon-ho Lee is a doctoral student in the Graduate School of Public Administration at Seoul National University.

**** Hyun-Jong Yoo is a professor at the Korean Civic Education Institute for Democracy.

Manuscript received October 21, 2012; out for review October 23, 2012; review completed December 6, 2012; accepted December 12, 2012.

The Korean Journal of Policy Studies, Vol. 27, No. 3 (2012), pp. 73-99.

(C) 2012 by the GSPA, Seoul National University 


\section{INTRODUCTION}

Since its foundation in 1948, the Republic of Korea has achieved state-building, industrialization, and democratization, in that order. In this relatively rapid national development, the state administration has played a leading role; by its nature, presidential leadership has been a most important factor. Presidential leadership is supported by the Constitution and other laws. It is also supported by diversely institutionalized core executive apparatuses, including the presidential secretariat (PS) and the central agencies. ${ }^{1}$ Through these staff organizations, the president as chief executive intervenes effectively in the activities of various administrative levels within the executive branch.

Presidential studies have been conducted from at least two different perspectives: the individual presidency perspective, focusing on the evolution of the presidency as defined by individual presidents (Pfiffner, 1994; Skowronek, 1982; Tulis, 1988), and the institutional presidency perspective, which examines changes in organizational structure, actors' incentives, and the resources of the presidency as an institution, considered independently from presidents' individual interests (Burke, 1992; Kessel, 1983; Moe, 1985). Among presidential studies that focus on the background and size of staffs and organizational change in Korea, only a few focused on the institutionalization (Hahm, 1999, 2002; J. Kim, 2003; Park, 2007). Additional research is needed on the institutionalization of the Korean presidency, including the period during which the Korean presidency emerged as an institution, not just an organization, and the level of institutionalization. This article analyzes the institutionalization of the PS by adopting the concept of institutionalization - that is, investigating how much the PS apparatuses have acquired autonomy with clear boundaries with the external environment, adaptability, and intra-organizational complexity or differentiation.

\section{THEORETICAL AND LEGAL BACKGROUND}

Institutionalization is a process by which an organization acquires value and stability by externally enhancing autonomy and adaptability while internally expanding its complexity and coherence (Huntington, 1968, p. 12; Selznick, 1957). An institutionalized organization is relatively well bounded or differentiated from its environment, durable, and internally complex, or it achieves universal norms and rules employed by

1. In this article, the presidential secretariat is differentiated from the central agencies, which are another important part of the core executive apparatus in Korea. For more detailed conceptual definitions and empirical data, see Jung, Lee, and Kim (2011). 
the leadership (Canon, 1989; Polsby, 1968). Institutions as formal and informal constraints are distinguished from organizations as the players of a game (North, 1990, pp. 4-5). An institution is more than an organization in that it acquires a distinctive identity, a way of acting, and tasks it acts on. A test to evaluate stability and value is the existence of expendability (Selznick, 1957). Thus, the beginning of an organization should be differentiated from its institutionalization. An organization evolves, by way of institutionalization, from a dispensable tool to an indispensable social entity with a unique way of doing its work.

In a study on the institutionalization of the American presidency from 1924 to 1992, Ragsdale and Theis (1997) suggested four factors: autonomy (the independence of the presidency from other units), adaptability (the longevity of units), complexity (the differentiation of sub-units and staff), and coherence (a manageable volume of work). ${ }^{2}$ According to this study, autonomy indicates the growth of an organization's budget and independent power to control decisions free from other parts of the government. Adaptability, or the duration of an organization, has two implications, flexibility and complexity. The former means that presidents must be able to create, modify, and eliminate units and ensure the durability of key units, while the latter refers to internal institutionalization that can be measured by the division of labor and specialization. Coherence implies the organization's ability to manage its workload. The authors conclude that the American presidency emerged as an institution in the 1970s, though the Executive Office of the President was created in 1939 (Ragsdale \& Theis, 1997, pp. 1286-1298).

This article analyzes the institutionalization of Korea's PS in terms of autonomy, complexity, and adaptability. Since the politico-administrative contexts of the United States and Korea are different, it is necessary add other indicators-for example, expenditures (to measure autonomy), duration of organizational unit (to measure adaptability), and organizational differentiation into intra-organizational units (to measure complexity). Also, Korea's PS has the legal and tacit authority to control the central agencies and other administrative organizations to assist the president.

This is primarily a descriptive study. It conducts a historical analysis of the PS's organizational and budgetary changes. The data for this study were collected from

2. Coherence means discretionary power to control the internal and routine works of organizations. For example, the Office of Management and Budget in the United States has developed routine clearance procedures for budgets, legislation, and executive orders (Ragsdale \& Theis, 1997, pp. 1297-1301). In Korea, these responsibilities are assigned to central agencies, including the Ministry of Strategy and Finance, and the PS has legal and tacit authority over the central agencies. 
published government handbooks, the archives of the PS, and Internet sources of government statistics. Unlike earlier studies, this study focuses on changes in the Korean presidency as an institution in itself. It is intended not only to analyze the changes in staff size and organizational configuration (e.g., Hahm, 1999; J. Kim, 2003), but also to evaluate the characteristics of the PS in terms of institutionalization.

To understand the institutionalization of the presidency, it is also necessary to review its legal foundation. The constitutional basis for the president's executive leadership differs greatly by country. For example, the US Constitution (Article II, Section 3) states only, "The president shall take care that the laws be faithfully executed, and shall commission all the officers of the United States" (Stillman, 1987). Korea has maintained a presidential executive system for more than 60 years with the sole exception of a parliamentary system that lasted less than one year, from June 1960 to May 1961. Korea's Constitution is more specific than the US Constitution in regard to the president's power over the executive branch in several ways.

First of all, the Constitution clearly states that the president is the head of the state, and thus has the highest position not only as decision-maker in the executive branch but also as representative of the state. ${ }^{3}$ The president appoints a prime minister with the approval of the National Assembly (Article 86), and appoints cabinet members (Article 87) and ministers (Article 94) with the recommendation of the prime minister. The Constitution also provides the president with authority to appoint the chair of the Board of Audit and Inspection, with the approval of the National Assembly (Article 98), and authority over the appointment and dismissal of public servants according to the law (Article 78).

Unlike the relatively specific articles on the president's authority over personnel administration, the Constitution states indirectly authorities over other key administrative functions such as policy planning, budgeting, organizing, legislating, and auditing and inspection. Article 54 of the Constitution, for example, allows the executive branch to submit a draft budget to the National Assembly. According to the subordinate National Finance Act, however, the finance minister has to submit the budget to the Cabinet and then receive the president's approval before submitting it to the National Assembly.

3. There was a general provision in Article 51 of the Founding Constitution (July 17, 1948) that "the president shall be the head of the executive branch and represent the state to foreign countries." This clause has remained the same through seven constitutional amendments, making the president formally the head of the state. The only exception was during the brief experiment with a parliamentary system described above. The president's dual status has been criticized as a cause of the Korean president's "personalization du pouvoir" or “imperial presidency" (Sung, 2008, pp. 292, 339). 
This provides the president with power to influence the budgeting process within the executive branch. Also, the Constitution states that a governmental reorganization may be conducted by law (Article 96), and that the executive branch possesses the right to submit such a bill. Therefore, the president may initiate administrative reorganization by submitting a reorganization bill, though the National Assembly ultimately decides whether to pass it.

The president appoints the chair of the Board of Audit and Inspection with the approval of the National Assembly, and the term of the board members including the chair is guaranteed in the Constitution (Article 98). Since the Board of Audit and Inspection is attached to the president, however, the president can exercise both direct and indirect influence over it. The Constitution also clearly states that the president may issue decrees on matters delegated to him by law within the scope specifically defined and also on matters necessary to enforce laws (Article 75). The prime minister or the head of an executive ministry may, under the powers delegated by law or presidential decree, issue ordinances (Article 95). These articles state that the president is subordinate to the law but has control over the executive branch through the authority to legislate over such ministerial ordinances and to inspect whether they violate a presidential decree.

The Constitution states that the local governments deal with administrative matters pertaining to the welfare of local residents, manage properties, and enact provisions relating to local autonomy, within the limit of laws and regulations. However, the president and central government have substantial power over local governments because they can submit bills to the National Assembly that determine the types of local governments and related laws, and they can issue a presidential decree or prime ministerial or ministerial ordinance in areas for which they have authority. The legal foundation for organizing the PS is not clear in the Constitution. Instead, the National Government Organization Act stipulates its purpose, size, and status. According to this Act, the president has the authority to control and supervise the heads of central administrative apparatuses (Article 11), and the PS is organized to assist the function of the president (Article 14).

In addition to this legal foundation, the chief executive needs to be supported practically by diverse core executive apparatuses for effective executive leadership. In any country with a presidential executive system, the PS is the core staff organization that supports the president. However, its size and configuration differ greatly according to country. In western industrialized countries, institutionalization of the core executive apparatuses mostly took place after the mid-20th century. Korea established the republic in the mid-20th century, much later than western industrialized countries. However, it has institutionalized more complex and heavily responsible core executive appara- 
tuses, including the PS and the central agencies. Among these, the PS has been the most powerful and important.

\section{FUNCTIONS AND RESOURCES}

In any country, regardless of whether it has a presidential or a parliamentary executive system, the secretariat to the chief executive (president or prime minister) is the key staff organization of the core executive (Dunleavy \& Rhodes, 1990; Peters, Rhodes, \& Wright, 2000; Pfiffner, 1994; Rose, 1984). In Korea, the presidential residence-cumsecretariat was called the Gyeongmudae during the Syngman Rhee administration (1948-1960) and then the Cheongwadae (or Blue House) beginning in 1960. ${ }^{4}$ During the past 60 years, the PS has been reorganized frequently, affecting its complexity, coherence, autonomy, and adaptability.

The size of the secretariat to the chief executive differs greatly according to country. For example, in Sweden, it had around 10 staff until the 1970s, whereas in Italy, it had 300 in 1963, 800 in 1980, and 4,000 in 1997. In the year 2000, a relatively small secretariat could be found in Denmark (85 staff), the United Kingdom (100), Ireland (a few), and Norway (14). Mid-sized secretariats existed in Australia (30 in the prime minister's residence, 343 in the prime minister's office and Cabinet), Canada (85 in the prime minister's office, 60 in the Privacy Council office), Germany (453 in the

Figure 1. Number of Staff in the Presidential Secretariat and the Prime Minister's Office, 1948-2011

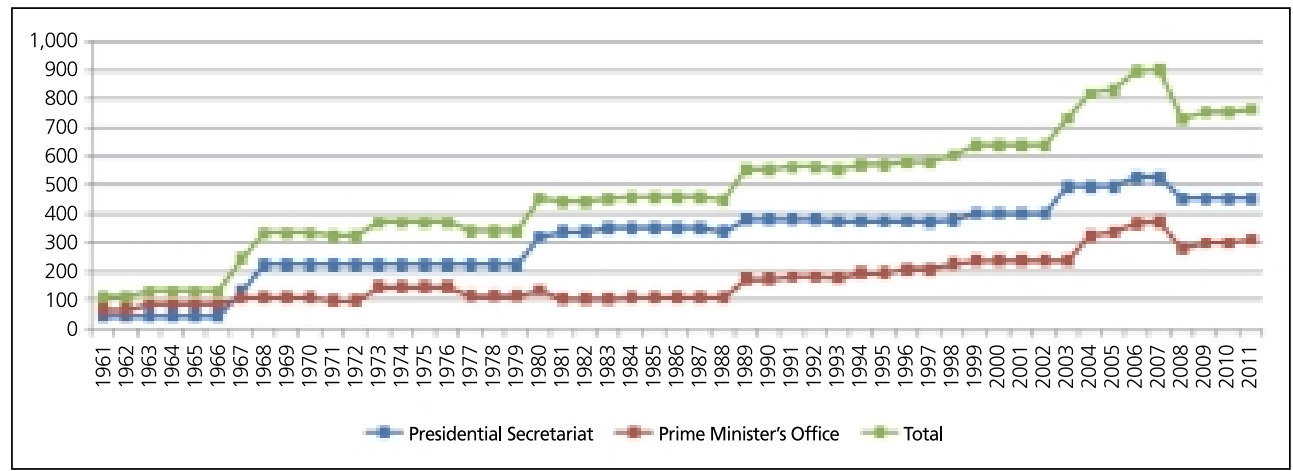

Sources: Information Center (n.d.); Jung (2012, p. 31).

4. During the Joseon Kingdom (1392-1910), a secretariat called the Seungjeongwon was institutionalized to assist the king (W. Kim, 1970). 
prime minister's office), and large secretariats in the United States (2,000), Italy $(4,000)$, and France $(5,000)$ (Peters et al., 2000).

Korea's PS has continually increased its staff, from fewer than 100 through the mid-1960s, to about 200 to 500, with a sole exception after 2008 when the Myung-bak Lee administration reduced its staff. If the staff of the Prime Minister's Office is included, however, the number one and two chief executives can be regarded as large, with 900 staff during the Moo-hyun Roh administration (figure 1).

Figure 2 shows the growing stability and autonomy of the PS in terms of expenditures, which were 15 million won in 1962 and increased almost 5,000-fold to 74,350 million won in 2011. Five breakpoints-1965, 1969, 1976, 1978, and 1990-reveal differences in the increasing values. The Chung-hee Park administration expanded the PS's organizational structure in 1968, which explains the increase in its expenditures at that time. While the Doo-whan Chun administration showed an incremental trend, the Tae-woo Rho administration increased expenditures sharply and then decreased them again. An unusual change in the PS's expenditures in 1989-1990 was caused by expanding its buildings. ${ }^{5}$ Beginning with the Young-sam Kim administration of 1993, the expenditures of the PS increased steadily. This steady increase in financial resources reflects its steady increase in autonomy.

Both staff size and level of organizational differentiation were very low in the PS from the Rhee administration (1948-1960) to the end of the first term of the Park

Figure 2. Expenditures of the Presidential Secretariat, 1965-2011

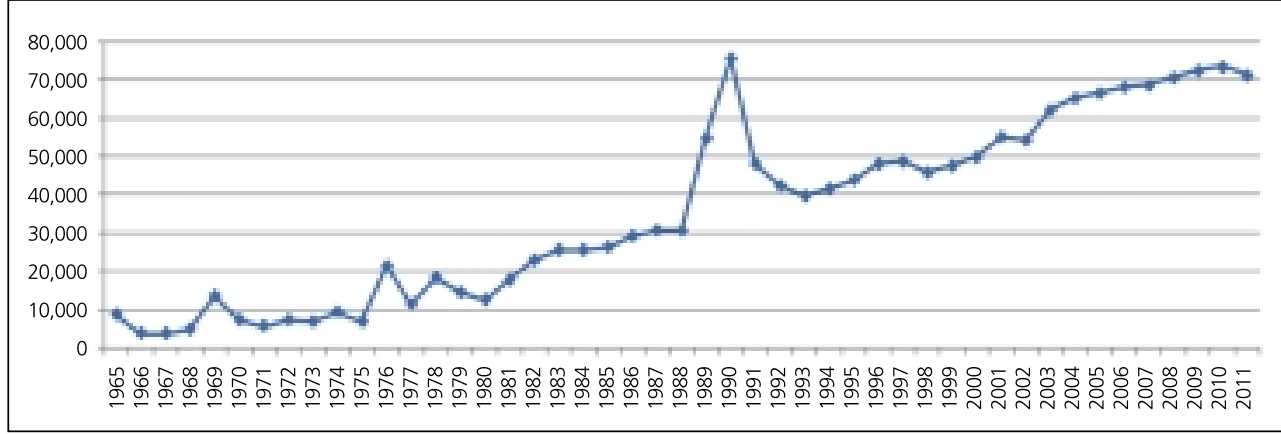

Sources: Appropriation and Budget System (n.d.); KDI (1990); Korean Statistical Information Service (n.d.). Unit is the 2010 value of Korean won.

5. Young-Gi Hong, a member of the National Assembly, accused the Rho administration of overspending for extending the residence building (Donga Ilbo, 1989); Presidential Office. n. d. "History of Cheongwadae." www.president.go.kr/kr/cheongwadae/history/history07 .php (accessed July 27, 2012) 
Figure 3. Presidential Secretariat as a Proportion of Total Administrative Apparatuses within the Executive Branch, 1948-2011

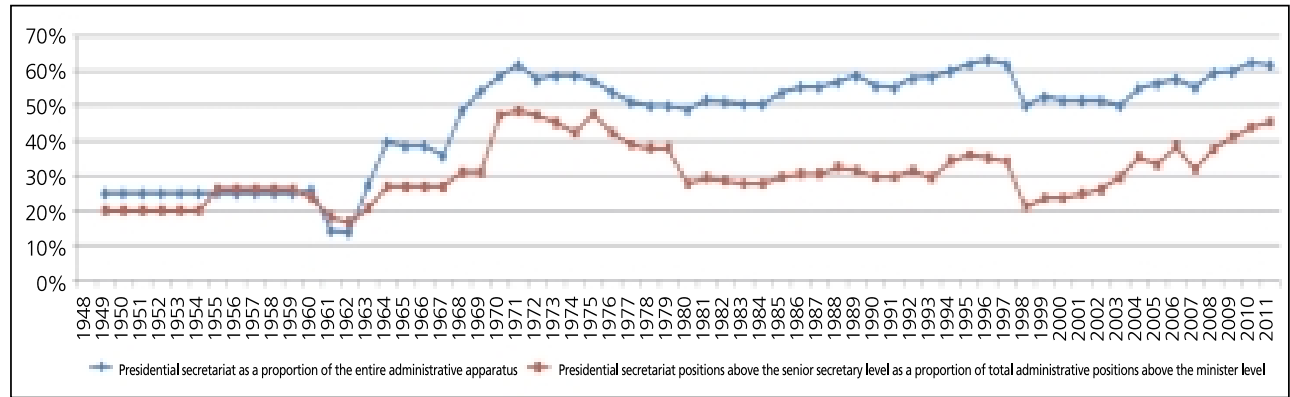

Sources: Information System (n.d.); M OGAHA (1998); M OL (n.d.); Presidential Office (n.d.); SOGA (1997).

Presidential secretariat positions include senior secretaries (including the Chief of Staff, Chief of Policy Staff, and Chief of the Planning Office), secretaries, and special advisors. The entire administrative apparatus includes ministries and ministrylevel commissions and boards, agencies, outer bureaus, and the presidential secretariat. Administrative apparatuses above the ministry level include ministries and ministry-level commissions and boards (including the audit institutions) and presidential secretariat positions above the senior-secretary level.

administration (1963-1967) (figures 3 and 4). The PS under Presidents Rhee (19481960) and Bo-sun Yoon (1960-1962) focused on basic internal, speech writing, protocol, and public relations - unlike their successors, who have actively conducted political and policy affairs, including the policy coordination of related ministries and agencies. The number of secretarial offices including Chief of Staff was only about 17 from May 1963 to July 1964, and it made up 27 percent of the total administrative apparatuses within the executive branch. Its size and proportion were reduced under the parliamentary government of President Yoon and Prime Minister Chang (figures 3 and 4).

Figure 4. Organizational and Staff Changes in the Presidential Secretariat, 1948-2011

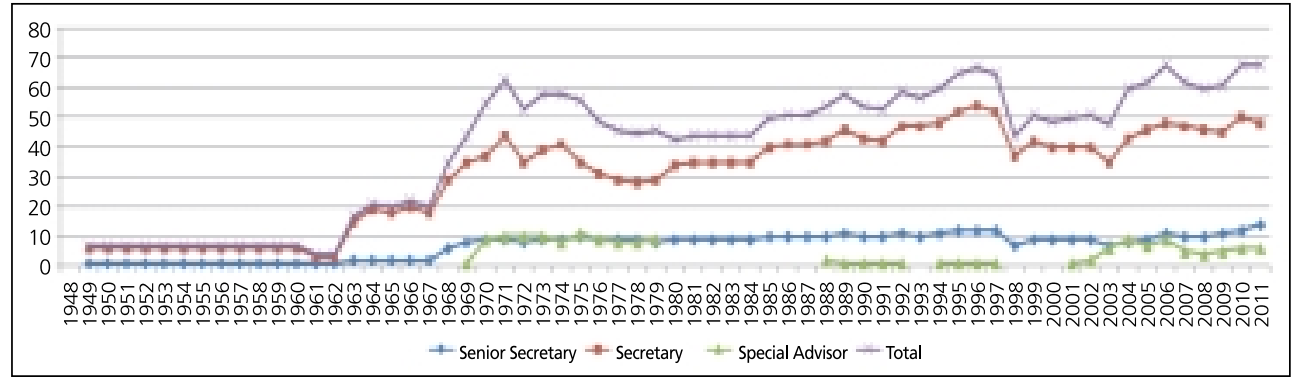

Sources: Presidential Archives (n.d.); Presidential Office (n.d.); SOGA (1997).

All secretaries under senior secretaries are included. The senior secretary category includes the Chief of Staff, Chief Senior Secretary for Policy, and senior secretaries. The secretary category includes not only the heads of secretary offices and team chief but also all the subordinates within (senior) secretary offices of teams. The special advisor category includes special advisors and advisors. The presidential security services are not included. 
At the beginning of President Park's second term in 1968, the PS began to grow in size and to be much more differentiated functionally through the creation of different sub-organizations for different public policy areas (figure 4). Most secretarial positions were upgraded to senior secretary, to be on par with ministers or vice ministers. About 10 senior secretary offices were created, and their proportion to the total ministeriallevel apparatuses within the executive branch increased from about 20-25 percent during the 1948-1960 period to 30-50 percent since 1967 (figure 3). The proportion of the PS's total apparatuses to the total administrative apparatuses increased from about 30 percent before 1967 to 50-60 percent after 1967. This change occurred right after the launching of Korea's second five-year economic development plan (1967-1971).

Special advisors have also sometimes been appointed for diplomacy, national security, politics, education and culture, social affairs, inspection and investigation, and other issues. Some of the special advisor positions were changed to senior secretary positions in 1980 by President Chun (1980-1988). Unlike special advisors, who worked alone with the aid of a few administrative assistants, the senior secretaries, as chiefs of a senior secretarial office, have been provided with a number of staff including director-general-level (grade 1 to 3 ) secretaries. Such senior secretary offices and special advisors, differentiated according to public policy areas, have been partially restructured by different presidents, but the basic format has been maintained, which shows its durability. Since 2003, the number and proportion of (senior or lower level) secretary offices have been increasing again (figures 3 and 4).

As a whole, the evolution of the PS during the past six decades can be categorized into three stages. At first, the PS was poorly institutionalized from the late 1940s to the late 1960s. Next, it was rapidly institutionalized with a dramatic expansion and differentiation of apparatuses from the late 1960s to the late 1980s. The Chun administration, succeeding the Park administration in the 1980s, attempted to reduce the total number of staff, mainly by abolishing special advisors, but increased instead the number of secretary offices (figure 4). Finally, presidents since the democratic transition in 1987 have effectively controlled expansion of the number of senior secretaries, but not the total size of the PS. The number of senior secretaries has decreased slightly, with slight fluctuations, but the number of secretaries increased during the Tae-woo Rho and Young-sam Kim administrations. The Dae-jung Kim and Moo-hyun Roh administrations reduced the number of senior secretaries and secretaries, but the Moo-hyun Roh administration appointed enough special advisors to increase the total presidential staff. Each government has expanded the PS during the latter part of its term. The rest of this section analyzes in more detail the institutionalization of the PS in different policy areas, focusing on organizational configuration. 


\section{General and Protocol Affairs}

General affairs within the PS, including document handling and recording, protocol, and liaison, are its most basic functions. From the beginning of the Rhee administration to the end of first term of the Park administration (1948-1967), this function was carried out by two secretarial offices. ${ }^{6}$ However, from the beginning of the second term of the Park administration to the end of the Young-sam Kim administration (1968-1997), the organization for this function was expanded with one or two senior secretary offices and about 10 secretary offices on average. Since the beginning of the Dae-jung Kim administration, when structural adjustment of the public sector was carried out due to the financial crisis of 1998, the apparatuses for general and protocol affairs have been shrunk, not only by downgrading senior secretary positions to secretary but also by reducing the number of staff (figure 5). The proportion of the apparatus for general and protocol affairs to the total apparatus was around 30 percent under the Rhee administration and has been about 15 percent since 1963 (figure 5).

Regardless of the changes in organizational size and proportion or officer's rank, however, the (senior) secretary offices for general and protocol affairs have sustained their status as the most basic apparatus of the PS since the beginning of the republic. In addition to such durability and differentiation, these apparatuses also have main-

Figure 5. Number and Proportion of Unitsfor General and Protocol Affairs in the Presidential Secretariat, 1948-2011

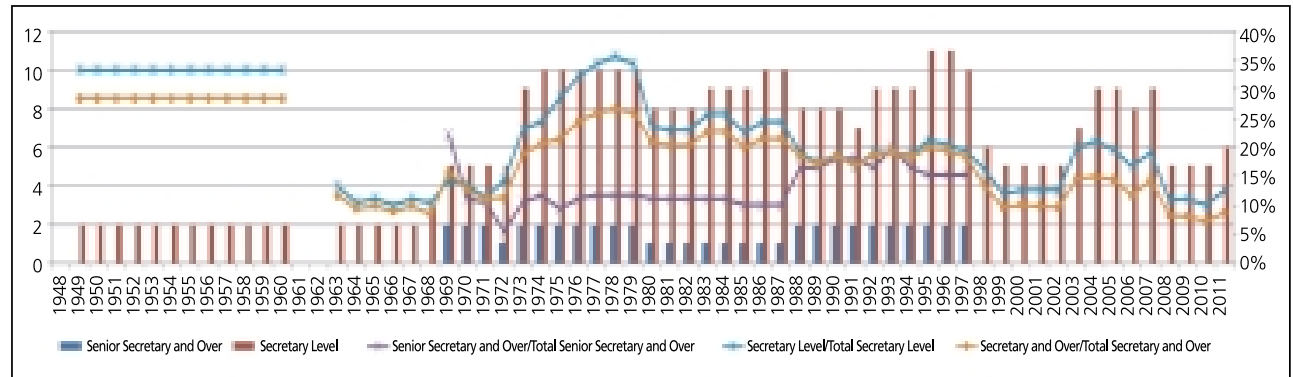

Sources: MOL (n.d.); Presidential Archives (n.d.); Presidential Office (n.d.); SOGA (1997).

"Senior secretary and over" includes the Chief of Staff, Chief of Policy Staff, senior secretaries (minister or vice minister level), and special advisors. "Secretary" includes R1- to R3-level staff. Staffs R4 level and lower are not counted. The functional status of the Office of the General Secretary was senior secretary level until 1967, but its civil service grade was 1. (Civil service grades were reorganized as grades 1-9 in 1980.)

6. As these offices are functionally independent, they are counted here as senior secretary offices, though their rank is grade 1 . These offices are functionally independent, but they are counted here as secretary offices, though their rank is grade 1. 
tained independence from and even strong power over others within the PS due to their staff functions, including schedule setting, staffing, and budgeting, not only for the other apparatuses but also for presidents and their families. The president's most loyal supporters have been appointed to these positions; they have sometimes been accused of malpractice and have sometimes been sent to prison.

\section{Public Relations}

Public relations, including the offices of spokesperson and the Secretary for Public Communications, is another basic function of the PS. From the beginning of the Rhee administration to the end of the first term of the Park administration, this function was conducted by two secretarial offices. From the beginning of the second term of the Park administration to the end of the Chun administration (1968-1987), the organization for this function was expanded to a maximum of one senior secretary and six secretaries. During the Tae-woo Rho administration, right after the democratic transition in 1987, the number of secretary offices for this function was first maintained at six; it dropped to three in 1992, but it increased again at the beginning of the Young-sam Kim administration (figure 6). The presidents since the democratic transition, with their civilian and political backgrounds, know very well the importance of public relations for governing and have increased the apparatus for that function. The proportion of the apparatus for public relations to the total apparatus was 18 percent at the most, with the exception of the military junta (1961-1963), during which time it was more than 50 percent (figure 6).

Figure 6. Number and Proportion of Units for Public Relations in the Presidential Secretariat, 1948-2011

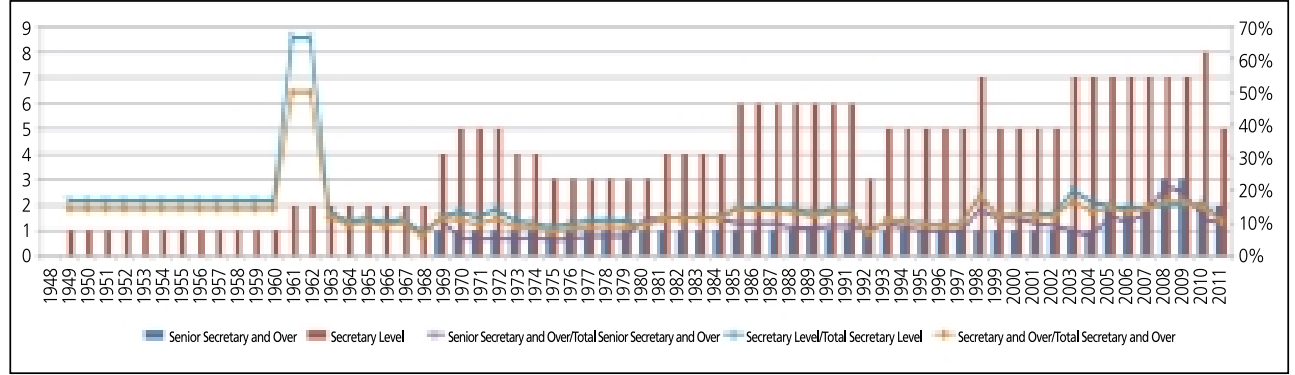

Sources: MOL (n.d.); Presidential Archives (n.d.); Presidential Office (n.d.); SOGA (1997).

"Senior secretary and over" includes the Chief of Staff, Chief of Policy Staff, senior secretaries (minister or vice minister level), and special advisors. "Secretary" includes R1- to R3-level staff. Staffs R4 level and lower are not counted. The functional status of the Secretary for Public Relations was independent at the same level as a senior secretary until 1967, but its civil senvice grade was 1. (Civil service grades were reorganized as grades 1-9 in 1980.) 
In addition to such durability and differentiation, this apparatus has maintained well its autonomy and legitimacy with well-boundedness from and authority over the external environment and other organizations within the PS. Regardless of the changes in its organizational size and proportion or officers' ranks, it has played a very important function in support of the president.

\section{Political and Administrative Affairs}

Most Korean presidents have established and made use of secretarial offices for politics and administration - the former for interactions with political parties, the National Assembly, and interest groups, and the latter for administrative reform, managing central-local relationships, and public security. These apparatuses have been sustained from the beginning of the Rhee administration to the present, with the exception of three years from the beginning of the parliamentary government (1960-1961) to the end of the military junta (1961-1963). Since the first term of the Park administration, which began in 1963, the Office of the Secretary for Political Affairs was restored and its head was upgraded to senior secretary. Under three administrations (1973-1998) Park's third term, Chun, and Young-sam Kim - the administrative affairs function was moved to the Office of the Senior Secretary for Administrative Affairs; later, the Daejung Kim administration (1998-2003) merged the two senior secretary offices into one, the Senior Secretary of Political Affairs.

The Moo-hyun Roh administration (2003-2008) removed the Office of the Senior Secretary of Political Affairs, and instead appointed one to four special advisors for

Figure 7. Number and Proportion of Units for Political and Administrative Affairs in the Presidential Secretariat, 1948-2011

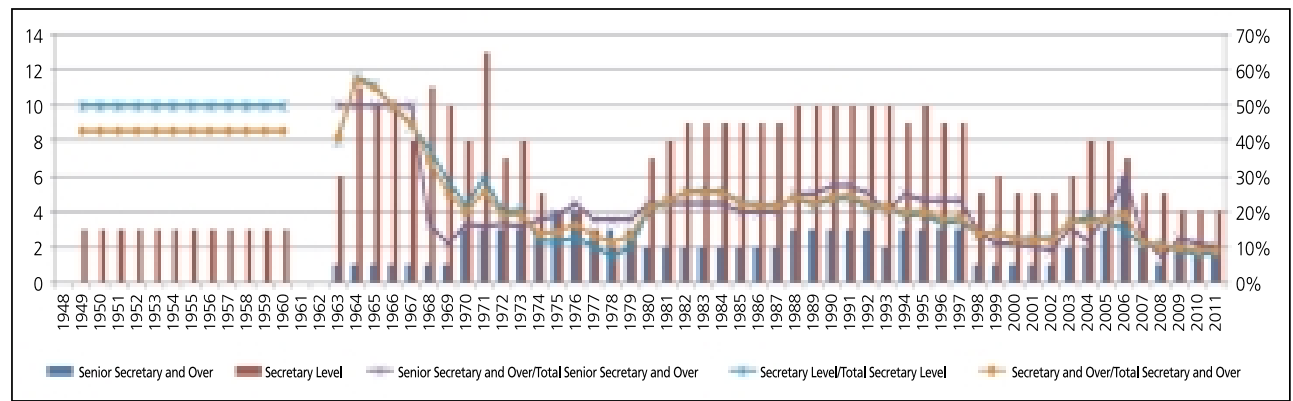

Sources: MOL (n.d.); Presidential Archives (n.d.); Presidential Office (n.d.); SOGA (1997).

"Senior secretary and over" includes the Chief of Staff, Chief of Policy Staff, senior secretaries (minister or vice minister level), and special advisors. "Secretary" includes R1- to R3-level staff. Staffs R4 level and lower are not counted. The functional status of the Secretary for Public Relations was independent at the same level as a senior secretary until 1967, but its civil service grade was 1. (Civil senvice grades were reorganized as grades 1-9 in 1980.) 
Figure 8. Relative Weight of the Political and Administrative Affairs Functions in the Presidential Secretariat, 1948-2011

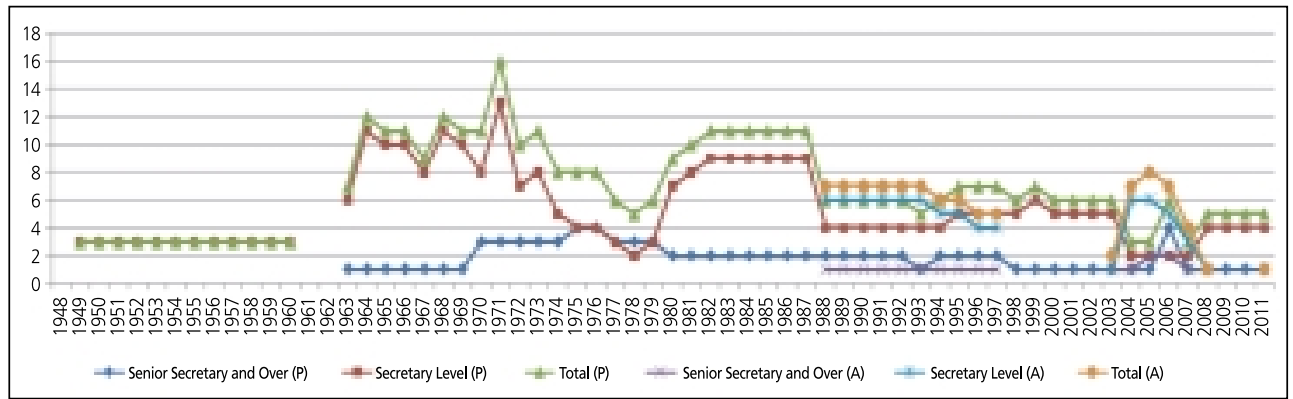

Sources: MOL (n.d.); Presidential Archives (n.d.); Presidential Office (n.d.); SOGA (1997).

$P=$ number of units under the Political Senior Secretary; $A=$ number of units under the Administrative, Personnel Management, and Innovation Senior Secretary.

politics and established the Office of the Senior Secretary for Personnel Management. The Lee administration (2008-present) has restored the Office of the Senior Secretary for Political Affairs and the Office of the Secretary for Personnel Planning, which is treated as a senior secretary office. The proportion of the apparatuses for political and administrative affairs to that for the total apparatus was around 50 percent from 1948 to 1968 , but has been about 20 percent on average since then (figure 7).

As seen above, the PS's unit for political and administrative affairs has been in place from the beginning of the republic. However, its durability, the proportion between the political and administrative functions, and its relative autonomy from or authority over other apparatuses within the PS have changed, depending on the political situation, the executive system, and the president's governing style (figure 8).

\section{Civil Affairs and Inspection}

Alone among the PS's executive organizations, those for civil affairs and inspection were not established until the Third Republic (figure 9). President Park appointed just one secretarial office with three officers for civil complaints in 1964, but expanded it to the Office of the Senior Secretary for Civil Affairs and the Special Advisor for Inspection (with six secretaries) from 1968 to 1979. These functions also began to be expanded, including not only civil affairs in the sense of dealing with civil complaints, but also investigation of malpractice by public officials, screening of intelligence reports, and judicial affairs. The Chun administration expanded the function further, establishing two new senior secretary offices, one for inspection (1980-1988) and another for judicial affairs (1985-1988). President Rho, the first president after the 
Figure 9. Number and Proportion of Units for Civil and Inspection Affairs in the Presidential Secretariat, 1948-2011

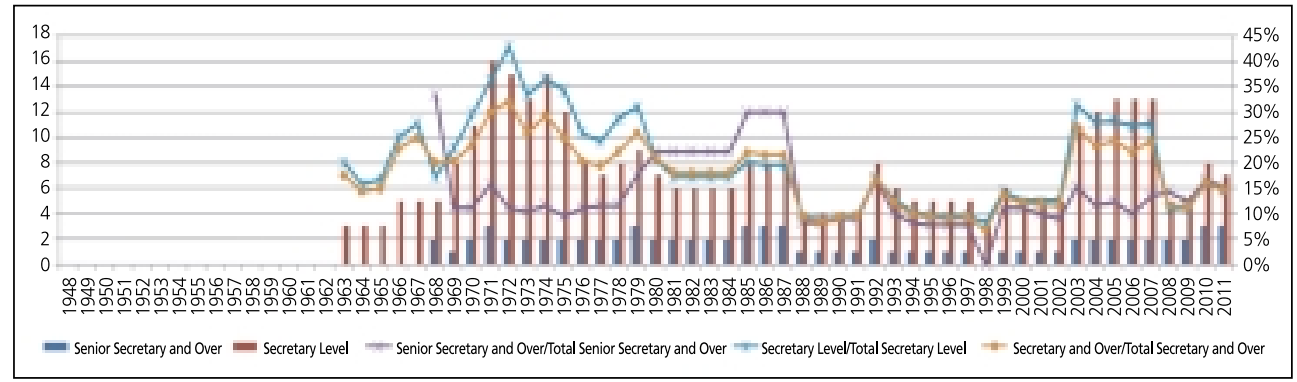

Sources: MOL (n.d.); Presidential Archives (n.d.); Presidential Office (n.d.); SOGA (1997).

"Senior secretary and over" includes the Chief of Staff, Chief of Policy Staff, senior secretaries (minister or vice minister level), and special advisors. "Secretary" includes R1- to R3-level staff. Staffs R4 level and lower are not counted. The functional status of the Office of the Civil and Inspection Secretary was independent at the same level as a senior secretary until 1967, but its civil service grade was 1. (Civil service grades were reorganized as grades 1-9 in 1980.)

democratic transition, removed the two senior secretaries in 1988, but upgraded the Office of the Senior Secretary for Civil Affairs to a minister-level position in 1990 and reestablished the Office of the Senior Secretary for Inspection in 1992.

Under the "civilian government" of President Young-sam Kim and the "people's government" of Dae-jung Kim, the Office of the Senior Secretary for Inspection was removed. The "participatory government" of President Moo-hyun Roh added the Office of the Senior Secretary for People's Participation (later the Office of the Senior Secretary for Civil Society) to handle functions such as communication with civil society and carrying out opinion surveys. The PS under the Lee administration began with the Office of the Senior Secretary for Civil Affairs and the Special Advisor for People's Integration, but soon established the new Office of the Senior Secretary for Social Integration to deal with civil rights, civil communication, and similar issues.

The proportion of the apparatus for civil affairs and inspection to the total PS apparatus was low, less than 15 percent, at the beginning of institutionalization in 1964, but increased dramatically, especially under the authoritarian governments (1973-1987), to 25-30 percent (figure 9). After the democratic transition, the proportion decreased to around 10 percent but increased dramatically again after 2003. This fluctuation can be explained by the characteristics of the different administrations. The Park and Chun administrations needed to expand the apparatuses mostly to investigate politicians, civil society, and the civil service to maintain their authoritarian rule, while the Roh and Lee administrations mostly sought communication with civil society under a democratized political environment.

While institutionalization of the PS's other apparatuses started as early as the 
beginning of the First Republic, it began for civil and inspection affairs at the beginning of the Third Republic. The size of this function and its proportion to the total PS changed a lot depending on the political situation and the president's governing style. However, its relative autonomy from and authority over other apparatuses within the PS have increased, for at least two reasons. First, inspection has been a necessary function to enable presidents to control public officials and to address personnel matters, especially when making appointments that require confirmation by the National Assembly. Second, presidents need to communicate effectively with civil society, which has become increasingly influential since the democratic transition.

\section{Foreign, National Security, and Reunification Affairs}

The Office of the Secretary for Foreign and National Security Affairs began to be institutionalized with the Office of the Secretary for Defense in 1961 (figure 10). Though there was no secretary for national security and diplomacy from 1963 to 1969 , there were three special advisors for national security (1968-1980) and for diplomacy (created in 1970). The number and proportion of units for foreign, national security, and reunification affairs in the PS decreased sharply in 1986 and 1987, when the Security Planning Committee moved from the PS to the Prime Minister's Office. Also, the number and size of the units for foreign, national security, and reunification affairs skyrocketed due to the expansion of the National Security Council (NSC) in the Moohyun Roh administration.

The units responsible for foreign, national security, and reunification affairs were

Figure 10. Number and Proportion of Units for Foreign, National Security, and Reunification Affairs in the Presidential Secretariat, 1948-2011

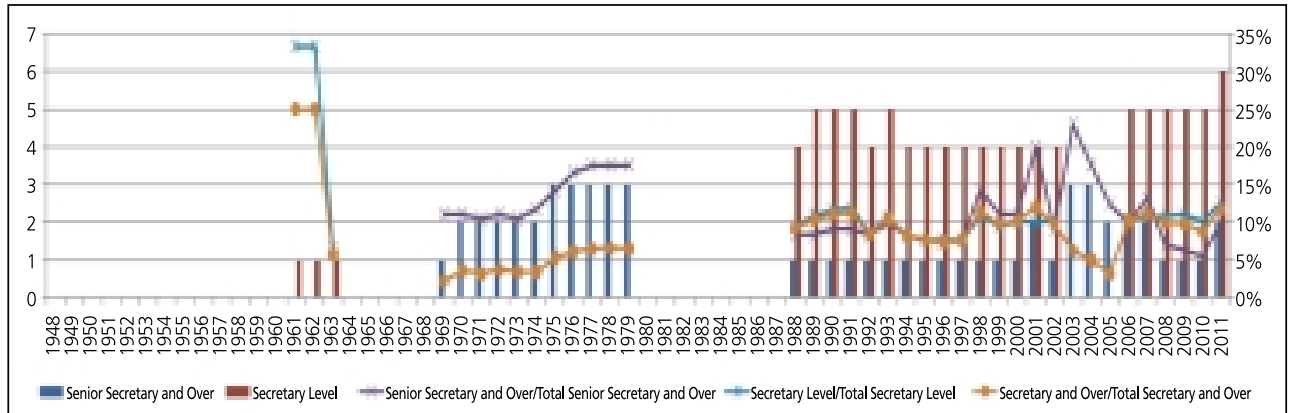

Sources: MOL (n.d.); Presidential Archives (n.d.); Presidential Office (n.d.); SOGA (1997).

"Senior secretary and over" includes the Chief of Staff, Chief of Policy Staff, senior secretaries (minister or vice minister level), and special advisors. "Secretary" includes R1- to R3-level staff. Staffs R4 level and lower are not counted. Organizational units outside the presidential secretariat are not included, though they are affiliated with the president. 
Figure 11. Number and Proportion of Secretarial and Affiliated Units for the Foreign, National Security, and Reunification Affairs, 1948-2011

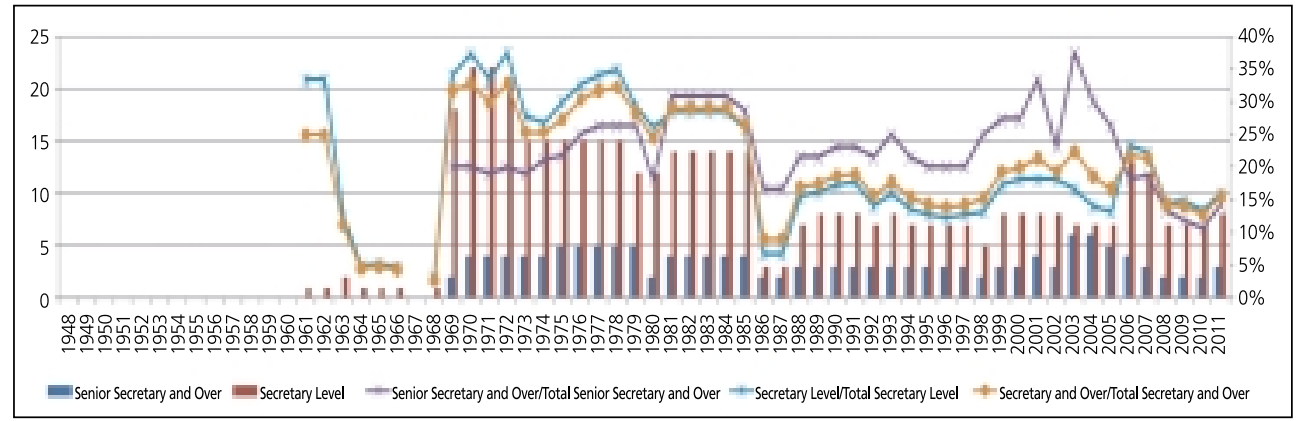

Sources: Information Center (n.d.); M OL (n.d.); Presidential Archives (n.d.); Presidential Office (n.d.); SOGA (1997).

"Senior secretary and over" includes the Chief of Staff, Chief of Policy Staff, senior secretaries (minister or vice minister level), and special advisors. "Secretary" includes R1- to R3-level staff. Staffs R4 level and lower are not counted. All the presidential secretariat's intra-organizational units and its affiliated external organizations are included.

less institutionalized from the 1960s to the late 1980s. Instead, President Park established two affiliated organizations, the NSC (1963-1980) and the Security Planning Committee (1969-1985), and President Chun established the People's Council for Peaceful Reunification (1981-present), a networking and mobilizing organization (figure 11). ${ }^{7}$

Right after the democratic transition, the units responsible for foreign, national security, and reunification affairs began to be sustained. President Tae-woo Rho established the post of Assistant to the President for National Security in 1988 and upgraded it in 1989 to Senior Secretary for Foreign and National Security Affairs, a post that is still in existence although it underwent some fluctuations under the Moo-hyun Roh administration. President Roh expanded and renamed the Office of the Senior Secretary to the Offices of the Assistant for National Security (minister level), the Assistant for Diplomacy (vice-minister level), and the Assistant for Defense (vice-minister level) in 2003. However, the Assistant for Defense post was abolished in 2005 and replaced with that of Vice Secretary General of the NSC (also vice-minister level). The NSC, though established in 1963, did not play an active role at first, with only one staff member from 1963-1980 and then with no staff from 1981-1998. The Dae-jung Kim administration revived the office with two staff (1998-2003), and Moo-hyun Roh

7. The Security Planning Committee moved to the Prime Minister's Office in 1986 and remained until 2008, when its functions were integrated into the Ministry of Public Administration and Security. The People's Council for Peaceful Reunification moved to the Ministry of Reunification in 1998 but returned to the PS in 1998. 
made it more active, appointing a Vice Secretary General, formally at the vice-minister level but in fact the most powerful position in that policy area. At the start of the Lee administration in 2008, the NSC again had no staff. However, experiencing military conflict in the West Sea with North Korea, President Lee established a new post of Senior Secretary for National Crisis Management (Jung \& Ahn, 2011).

The proportion of the units for foreign, national security, and reunification affairs to the total units of the PS was very unstable, ranging from 0 to more than 10 percent. If the affiliated units including the NSC, Security Planning Committee, and People's Council for Peaceful Reunification are included, however, their proportion to the total units of the PS is somewhat more stable (figure 11).

As a whole, the institutionalization of the PS's apparatus for these functions has been relatively low, with little autonomy, well-boundedness, or durability but high with intra-organizational complexity or differentiation.

\section{Economic and Industrial Affairs}

The secretarial apparatuses for economic and industrial affairs began to be institutionalized with the appointment of two Senior Secretaries for Economic Affairs and seven secretaries in 1968 at the start of the second term of President Park. These were differentiated into three senior secretary offices in 1972, when the second and third five-year economic development plans (1968-1972 and 1973-1978) were implemented (figure 12). Since the early 1960s, the Korean government had aggressively pursued economic development and established many economic and industrial policy apparatuses, including the Economic Planning Board, Ministry of Finance, Ministry of Agriculture

Figure 12. Number and Proportion of Units for Economic and Industrial Policies in the Presidential Secretariat, 1948-2011

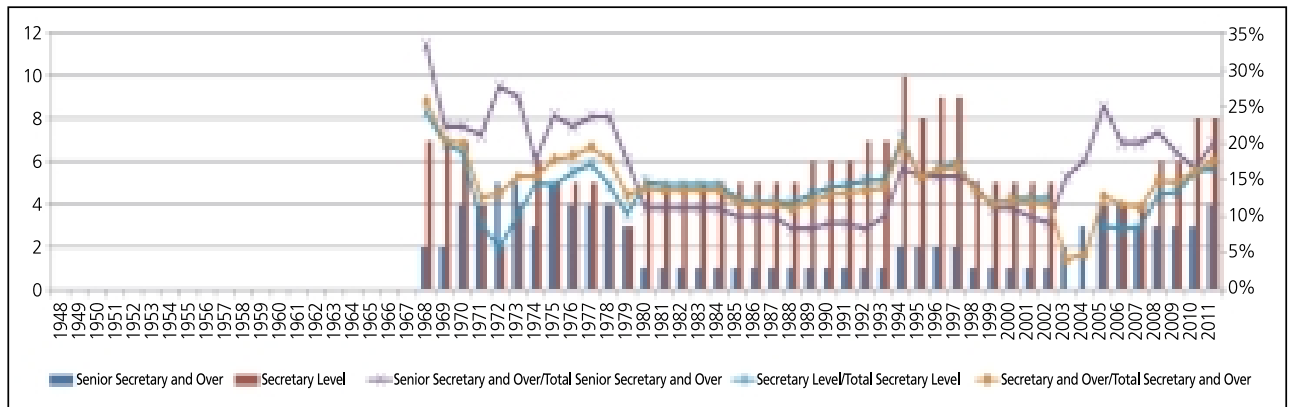

Sources: MOL (n.d.); Presidential Archives (n.d.); Presidential Office (n.d.); SOGA (1997).

"Senior secretary and over" includes the Chief of Staff, Chief of Policy Staff, senior secretaries (minister or vice minister level), and special advisors. "Secretary" includes R1- to R3-level staff. Staffs R4 level and lower are not counted. 
and Forestry, Ministry of Commerce and Industry, Ministry of Construction, and many affiliated agencies. President Park expanded and strengthened the PS's apparatus for incorporating these differentiated administrative organizations into overall national policy, especially beginning in the late 1960s. From that time, the Office of the Senior Secretary for Economic Affairs has been maintained, with the exception of two years (20032005) during which it was downgraded to Assistant Officer for Economics.

The proportion of these units in the PS fluctuated: 13-26 percent (with 18-28 percent at the senior secretary level) during the Park administration, dropping to around 15 percent during the Chun and the Young-sam Kim administrations, 12-14 percent during the Dae-jung Kim administration, and around 5 percent during the first half of the Moo-hyun Roh administration, and then expanding continually to 18 percent under the Lee administration (figure 12). The high proportion under the Park and the Dae-jung Kim administrations might be caused by the government's industrialization policies and further government-led reforms after the foreign liquidity crisis of 1997. The lower proportion under the Moo-hyun Roh administration might be explained by its emphasis on social integration and participation and the establishment of the Chief of Policy Staff (ministerial level) office. The Roh administration also established six advisor positions-for personnel, defense, national security, diplomacy, information and scientific technology, and economy. The Lee administration established the seniorsecretary-level Office for Strategic Planning for the Future and for Green Growth, which can be included in the economic affairs category.

As a whole, the secretarial apparatus for economic and industrial affairs has been well institutionalized, with durability, intra-organizational complexity or differentiation, and legitimacy with authority over other units within the PS, although it has comparatively somewhat less autonomy from the external environment.

\section{Social and Educational Affairs}

Socio-cultural affairs was the last aspect of the PS to be institutionalized (figure 13). President Park appointed special advisors for education and culture and for social affairs during the 1970s for the first time in Korea. During the Chun administration (1980-1988), the Office of the Senior Secretary for Education and Culture was established; it was changed into the vice-ministerial-level Office of the Policy Assistant to the President for Social Affairs during the Tae-woo Rho administration. President Young-sam Kim restored the Office of the Senior Secretary for Education and Culture in 1993 and changed it to the Office of the Senior Secretary for Social Welfare in 1995. His successor, Dae-jung Kim, changed it to the Office of the Senior Secretary for Welfare and Labor and restored the Office of the Senior Secretary for Education 
Figure 13. Number and Proportion of Units for Social, Educational, and Cultural Affairs in the Presidential Secretariat, 1948-2011

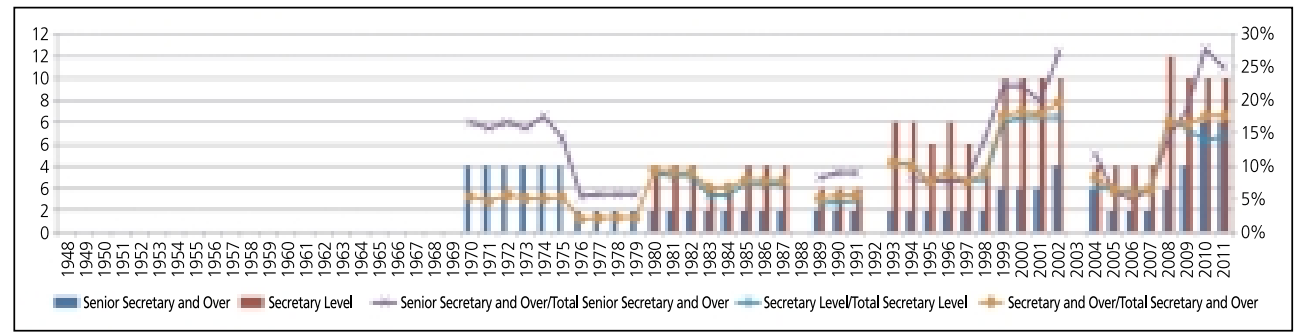

Sources: MOL (n.d.); Presidential Archives (n.d.); Presidential Office (n.d.); SOGA (1997).

"Senior secretary and over" includes the Chief of Staff, Chief of Policy Staff, senior secretaries (minister or vice minister level), and special advisors. "Secretary" includes R1- to R3-level staff. Staffs R4 level and lower are not counted. The Science Secretary position was located within the Office of the Senior Secretary for Education, Science, and Culture during 20082009, but moved to the Future Planning Strategy Office in 2010.

and Culture in 1999. President Moo-hyun Roh reduced the secretarial units for these functions by integrating them into the Office of the Senior Secretary for Social Policy in 2004. President Lee restored the Office of the Senior Secretary for Education and Culture and changed the Office of the Senior Secretary for Social Policy to the Office of the Senior Secretary for Employment and Welfare.

The proportion of the units for socio-cultural affairs to the total units of the PS has been relatively low, at less than 20 percent (figure 13). The proportion of different functions, including education, culture, social welfare, labor relations, employment, gender, family, and multicultural affairs, has fluctuated depending on the policy emphasis of each president. For example, the Moo-hyun Roh administration made use of three task forces reporting to the Chief of Policy Staff and three policy planning committees reporting to the president. ${ }^{8}$

As a whole, the function of social and cultural affairs has been institutionalized continually, though it began late and has experienced more change than other functions.

\section{Steering and Coordination within the Presidential Secretariat}

Since the beginning of the First Republic, the Chief of Staff (figure 14) has been in charge of coordinating all the staff and secretarial offices within the PS. The more the PS has been differentiated and expanded, however, the more it has needed func-

8. These were the Task Forces on Reducing the Income Gap and Correcting Discrimination, Labor-Relations Reform, and Rural Development, and the Committees on Correcting the Income Gap and Discrimination, Aging and Future Society, and Educational Reform. 
Figure 14. Number and Proportion of Units for Steering and Coordination within the Presidential Secretariat, 1948-2011

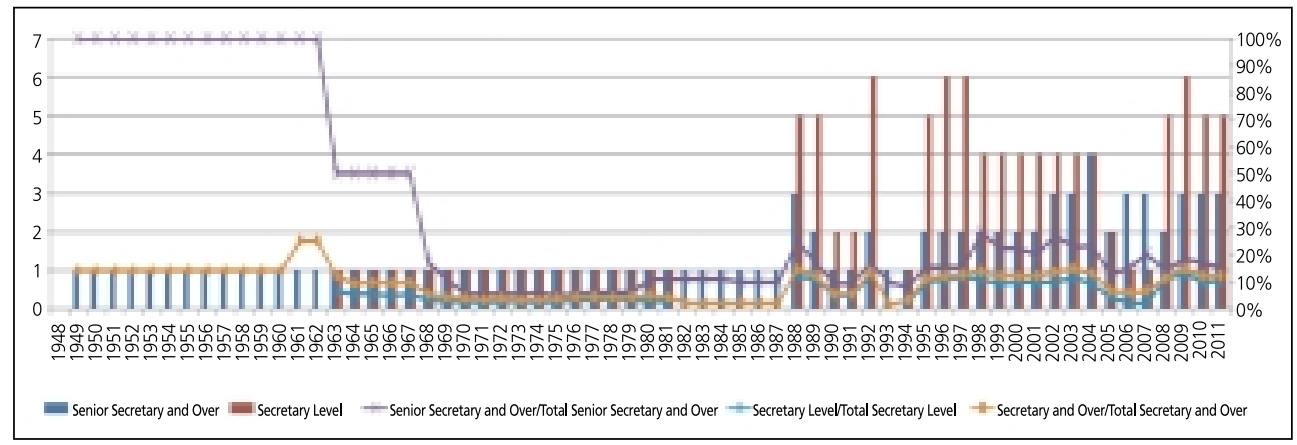

Sources: MOL (n.d.); Presidential Archives (n.d.); Presidential Office (n.d.); SOGA (1997).

"Senior secretary and over" includes the Chief of Staff, Chief of Policy Staff, senior secretaries (minister or vice minister level), and special advisors. "Secretary" includes R1- to R3-level staff. Staffs R4 level and lower are not counted.

tional integration and coordination. Each (senior) secretary office has been in charge of steering usually several ministries and agencies in the related policy area. Thus, the former has tended to represent the policy perspectives of the latter. As the complexity of the PS increased, difficulties in policy coordination have occurred not only at the Cabinet level (between ministries or agencies) but also at the PS level (between secretarial offices). This led Presidents Tae-woo Rho and Young-sam Kim to establish the Policy Staff (vice-minister level, 1988-1989) and the Office of the Senior Secretary for Policy Planning (1995) to horizontally coordinate the secretarial offices based on policy functions (Jung, 2012, p. 3031).

These attempts to facilitate policy coordination within the PS were not effective, and the Senior Secretary for Policy Planning had to maintain his position by initiating new "blue ocean" tasks in which other senior secretaries were not very interested. President Moo-hyun Roh attempted to resolve the problem of policy coordination within the PS more aggressively, establishing the positions of Senior Secretary for Policy and Chief of Policy Staff in charge of coordinating between the policy-related (senior) secretaries. Since then, a two-headed system with both a Chief of Staff and a Chief of Policy Staff has been institutionalized in the PS. The Chief of Staff has had overall responsibility for the executive functions, including such traditional secretariat responsibilities as internal administration and protocol, public relations, political affairs, civil affairs, and foreign and national security policies, while the Chief of Policy Staff has overall responsibility for coordinating domestic policies. ${ }^{9}$

9. In addition to the secretarial units within the PS, many task forces have assisted the president 
The proportion of the organizational units for steering and policy coordination to the total units of the PS has been low at less than 20 percent. The Chief of Staff and Chief of Policy Staff have been formally designated as minister-level positions, but they have played a much more powerful role in fact. For example, many former chiefs of staff, including Hu-rak Lee and Chung-yum Kim of the Park administration, Jaebong Roh of the Chun administration, and Jie-won Park of the Dae-jung Kim administration, were regarded de facto as the second most powerful person after the president, although the prime minister formally has this status. The necessity of more effective policy coordination within the PS has provided the two chief offices with autonomy, legitimacy, and authority over other units despite their small size and low level of intra-organizational differentiation. The two-head system has caused the PS to operate more hierarchically than collegially.

\section{AUTONOMY, ADAPTABILITY, AND COMPLEXITY}

The PS started as a tiny organization during the Rhee administration. The Park administration reinvented it in 1963 by increasing the size of its staff and expanding its functions to include not only protocol but also political and policy affairs. The institutional presidency in the modern sense began around that time. Considerable time was needed for the PS to become fully institutionalized; its size and functions have been increased and differentiated almost steadily since 1948. This institutionalization process can be analyzed in terms of three factors: autonomy, adaptability, and complexity.

\section{Autonomy}

The autonomy of the PS has increased in terms of its budget and its authority over other organizations. PS expenditures show four breakpoints-1969, 1976, 1978, and 1990. The year 1969 coincided with the expansion of the PS with the establishment of the sub-unit of senior secretary.

Another source of autonomy is the power to control administrative apparatuses. The staffing structure of the PS has mainly been dependent on a centralization strategy.

on policy coordination. These have included the 21st Century Committee for President Tae-Woo Rho; the Segehwa (Globalization) Promotion Committee for President Youngsam Kim; the Policy Planning Committee for Presidents Dae-jung Kim, Moo-hyun Roh, and Myung-bak Lee; and the Presidential Council for Future and Vision for President Myung-bak Lee. 
Senior secretaries and secretaries work most closely with the president in terms of physical distance and communication, and this has provided them with greater decisionmaking power compared to the personnel of other administrative organizations. Ministers or agency administrators who wish to discuss a policy issue with the president must first discuss it with the relevant senior secretary, who will then decide the theme and time of the meeting and be present at it (Jung, 2012). This decision-making process has given the PS significant autonomy and allowed it to function like a de facto inner cabinet (Jung, 2012). Until now, each (senior) secretary office has been in charge of several related administrative apparatuses and has taken a top-down approach to steering and coordination of policy making and implementation. ${ }^{10}$ This top-down approach has been maintained since the PS system began to be institutionalized in the 1960s, even after the democratic transition in 1987.

Ever since the First Republic, the PS has faced legitimacy issues and a negative image as an authoritarian "center of power" (Jung, 2012, p. 31). Especially since the democratic transition, successive presidents have attempted to reduce its role and its staff and to decentralize policy making and coordinate power with the prime minister and ministers at the beginning of their administrations, but have eventually increased its size and role again. Presidents have had to allow a more active role for the core executive apparatuses because they rely on them to effectively implement the public policies that they promised to pursue when they were running for office.

\section{Adaptability}

Once a PS is institutionalized, its key apparatuses are not easy to change even when the president changes. The adaptability of the PS differs with the ability of different apparatuses to react to changing environments and demands. The executive functions of Korea's PS were launched as early as the First Republic in 1948, and have been expanded and differentiated since the 1960s. PS units for public relations, political and administrative affairs, and civil inspection were expanded with the establishment of a senior secretary post and several secretary posts in 1968, and have maintained their status since then.

PS units for policy functions began to be established later than those for executive

10. As of 2012, for example, the Senior Secretary for Economic Affairs is in charge of the Ministry of Strategy and Finance; the Ministry of Food, Agriculture, Forestry, and Fisheries; the Ministry of Knowledge Economy; the Ministry of Land, Transport, and Maritime Affairs; the Fair Trade Commission; and the Financial Service Commission, to name only the ministry-level apparatuses. 
Figure 15. Number and Proportion of Apparatuses with Executive and Policy Functions in the Presidential Secretariat, 1948-2011

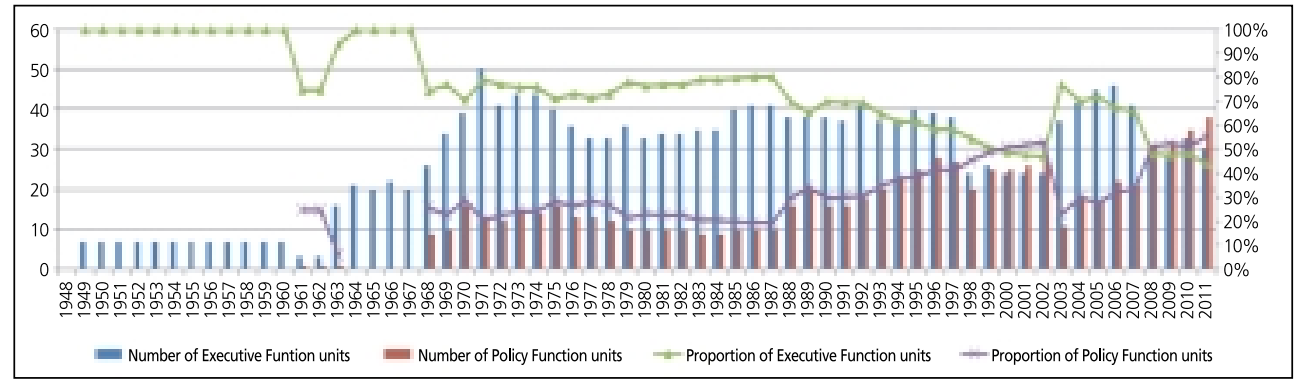

Sources: MOL (n.d.); Presidential Archives (n.d.); Presidential Office (n.d.); SOGA (1997).

Executive functions include such traditional secretariat responsibilities as internal administration and protocol, public relations, political affairs, and civil affairs. Policy functions include economic and industrial policy, foreign and national security policy, social policy (social welfare, health, labor, environment, and education), and cultural affairs. Staffs R4 level and lower are not counted.

functions. The majority of PS apparatuses had an executive rather than a policy function until the Dae-jung Kim administration, when the two functions became more equally represented (figure 15). The secretarial apparatuses for economic and industrial affairs were established in 1963, those for socio-cultural affairs in 1980, and those for foreign affairs, national security, and reunification as late as 1988. The durability of these units has also been low, with many fluctuations in terms of size, ranks of staff, and other aspects. If only the executive and economic policy functions are included, the starting point for acquiring adaptability is 1968. Otherwise-if foreign, national security, and reunification affairs and socio-cultural and educational affairs are added-the starting point for adaptability is 2004 .

\section{Complexity}

The complexity of the PS can be measured by the organizational differentiation into sub-units and specializations. The PS can be considered to have acquired organizational complexity in 1968, when it began to be stratified with senior secretary and secretary positions and expanded in size with the creation of many policy sub-units. It began to incorporate special advisors on economic and foreign policy in 1969. Bureaucrats from each ministry began to be dispatched into the PS, which enhanced its specialization.

The PS has been staffed mainly with public servants and outside experts rather than politicians. On average, 56 percent and 32 percent of staff at the senior secretary level and above have been public servants (including career civil servants, military 
personnel, and judicial bureaucrats) or outside experts (including university professors and professional researchers, business people, bankers, and journalists), while only 9.2 percent on average have been politicians (including members of political parties, the National Assembly, and local councils and chief executives). The proportion of politicians in Korea's PS is about half that of its counterpart in the United States (17.3 percent) (Park, 2007, pp. 67-87). Almost no politicians were appointed to the PS at the senior secretary or secretary level from the Rhee administration to the Rho administration, but the proportion increased to 40 percent under Yong-sam Kim and has remained stable at about 20 percent since then (Donga Yearbook, 1997-2010; J. Kim, 1997). Such an apolitical personnel composition might lead the PS's policy perspective to be guided by bureaucrats or professionals rather than politicians, thus orienting it toward the long term and consistency rather than the short term and flexibility (Jung, 2012).

As a whole, Korea's PS began to be institutionalized around 1968. Its expenditures increased sharply in 1969, and its organizational structure was stratified by adding the senior secretary rank in 1968. The institutionalization of the executive and economic policy functions of the PS was attained in 1968. But the institutionalization of the PS as a whole has not been completed. As issues such as national security and socio-cultural and educational affairs increased in importance, new sub-units have been created, abolished, and recreated.

\section{CONCLUSION}

The institutionalization of the PS in Korea, from the foundation of the republic in 1948 to the present, can be summarized as follows. The Korean president has maintained dual status under the Constitution as head of the executive branch and head of state except during the Second Republic (1960-1961). In 1963, the PS began to be institutionalized in a legal sense as a formal administrative apparatus under the National Government Organization Act. Before 1961, it had been only a subsidiary organ operating without a formal legal basis.

Change and continuity in the PS can be categorized into three stages. It was poorly institutionalized from the late 1940s to the late 1960s. It was rapidly institutionalized, with a dramatic expansion and differentiation of apparatuses, from the late 1960s to the late 1980s. Finally, presidents since the democratic transition in 1987 have effectively controlled expansion of the number of senior secretaries, which has actually decreased slightly (with some fluctuations), but not the total size of the PS. Each government has increased the size of the PS during the latter part of its term. 
Korea's PS has been a core institution for executive and economic policy functions since 1968. At that time, its expenditures began to increase steadily, enhancing its autonomy. Its organizational differentiation began to increase after that, and the status of key units has been maintained since then. During that time, the second and third five-year economic development plans were implemented to foster heavy and chemical industry. The PS as an institution has responded to changing environmental challenges. Public relations, political and administrative affairs, civil inspection, and foreign and national security affairs were institutionalized by the 1980s. Since the democratic transition of 1987, presidents have also considered more seriously institutionalizing socio-cultural, welfare, and education affairs.

The PS has been highly professionalized. It has been staffed, and thus its policy perspective has likely been guided, mainly by public servants and outside experts rather than politicians. This professionalization has made the PS oriented toward the long term and consistency rather than the short term and flexibility.

\section{REFERENCES}

Appropriation and Budget System of National Assembly. n.d. http://nafs.assembly .go.kr:83/.

Burke, J. 1992. The institutional presidency. Baltimore, MD: Johns Hopkins University Press.

Canon, D. 1989. The institutionalization of leadership in the U.S. Congress. Legislative Studies Quarterly, 14: 415-453.

Donga yearbook [in Korean]. 1997-2010.

Donga-Ilbo. 1989, December 4. n. d. www.donga.com (accessed November 27, 2012)

Dunleavy, P., \& Rhodes, R. 1990. Core executive studies in Britain. Public Administration, 68(1): 29-60.

Hahm, S. 1999. The Korean presidency [in Korean]. Nanam: Pajoo.

Hahm, S. 2002. The institutional development of Blue House in the Park Chung Hee presidency. Asian Perspective, 26(2): 101-130.

Huntington, S. 1968. Political order in changing societies. New Haven, CT: Yale University Press.

Information Center for Government Laws and Ordinances. n.d. http://www.law.go.kr/ (accessed July 27, 2012).

Information System for Government Organizational Management. n.d. http://www.org .mopas.go.kr/org (accessed July 27, 2012).

Jung, Y. 2012. The evolution of institutional presidency in Korea, 1948-2010. Japanese 
Review of Political Society, 1(1): 27-44.

Jung, Y., \& Ahn, J. 2011. Building a governance system in preparation for Korean reunification [in Korean]. Korean Journal of Public Administration, 49(2): 295326.

Jung, Y., Lee, Y., \& Kim, D. 2011. The institutionalization of the central agencies in Korea, 1948-2010. Korean Journal of Policy Studies, 26(1): 21-48.

KDI (Korea Development Institute). 1990. Forty years of Korean fiscal finance 1-2 [in Korean]. Seoul: Author.

Kessel, J. 1983. The structure of the Carter White House. American Journal of Political Science, 27: 431-463.

Kim, J. 1997. A study on the change of the organization and function of the Korean presidential secretariat [in Korean]. Master's thesis, Ewha Woman's University, Seoul.

Kim, J. 2003. An Institutional Analysis of the Korean Presidential Office From 1963 to 2001: John Burke's Model of Institutionalization and its Applicability to Korea [in Korean]. Korean Public Administration Review, 37(1). 225-248.

Kim, W. 1970. The political and administrative history of Joseon Kingdom [in Korean]. Seoul: Pakyoungsa.

Korean Statistical Information Service. n.d. http://kosis.kr (accessed July 27, 2012).

MOGAHA (Ministry of Government Administration and Home Affairs). 1998. A history of Korean government organizations [in Korean]. Seoul: Seongjin Munhwasa.

MOL (Ministry of Legislation). n.d. Government organization. www.law.go.kr (accessed July 27, 2012).

Moe, T. 1985. The politicized presidency. In J. E. Chubb \& P. E. Peterson (eds.), The new direction in American politics. Washington, DC: Brookings Institution.

North, D. 1990. Institutions, institutional change, and economic performance. New York: Cambridge University Press.

Park, D. 2007. A comparative analysis on institutional presidency: With an emphasis on Korea and USA. Korean Public Administration Review, 41(4): 67-87.

Peters, B. G., Rhodes, R., \& Wright, V. (eds.). 2000. Administering the summit: Administration of the core executive in developed countries. Chippenham, Wiltshire, UK: Antony Rowe.

Pfiffner, J. 1994. The modern presidency. New York: St. Martin's Press.

Polsby, N. 1968. The institutionalization of the U.S. House of Representatives. American Political Science Review, 62: 144-168.

Presidential Archives. n.d. http://www.pa.go.kr (accessed July 27, 2012).

Presidential Office. n.d. http://www.president.go.kr/kr/index.php (accessed July 27, 2012). 
Ragsdale, L., \& Theis, J. J., III. 1997. The institutionalization of the American presidency, 1924-92. American Journal of Political Science, 41(4): 1280-1318.

Rose, R. 1984. The capacity of president. Glasgow: University of Strathclyde.

SOGA (Secretary Office for General Affairs). 1997. The handbook of the presidential secretariat [in Korean].

Selznick, P. 1957. Leadership in administration. Evanston, IL: Row, Peterson.

Skowronek, S. 1982. Building a new American state: The expansion of national administrative capacities, 1877-1920. Cambridge, UK: Cambridge University Press.

Stillman, R., II. 1987. The American bureaucracy. Chicago, IL: Nelson Hall.

Sung, N. 2008. The constitutional context: Constitutional discontinuity and administrative continuity [in Korean]. In Korea Institute of Public Administration (ed.), Korean Public Administration, 1948-2008. Paju: Bobmunsa.

Tulis, J. 1988. The rhetorical presidency. Princeton, NJ: Princeton University Press. 